Article

\title{
Sustainable Growing Media Blends with Woody Green Composts: Optimizing the N Release with Organic Fertilizers and Interaction with Microbial Biomass
}

\author{
Bart Vandecasteele ${ }^{1, * \mathbb{D}}$, Koen Van Loo ${ }^{1}$, Sarah Ommeslag ${ }^{1}$, Siebert Vierendeels ${ }^{1}$, Maxim Rooseleer ${ }^{2}$ \\ and Elke Vandaele ${ }^{2}$
}

Citation: Vandecasteele, B.; Van Loo, K.; Ommeslag, S.; Vierendeels, S.;

Rooseleer, M.; Vandaele, E.

Sustainable Growing Media Blends with Woody Green Composts: Optimizing the N Release with Organic Fertilizers and Interaction with Microbial Biomass. Agronomy 2022, 12, 422. https://doi.org/ 10.3390 /agronomy 12020422

Academic Editor: Mariangela Diacono

Received: 4 January 2022

Accepted: 4 February 2022

Published: 8 February 2022

Publisher's Note: MDPI stays neutral with regard to jurisdictional claims in published maps and institutional affiliations.

Copyright: (c) 2022 by the authors. Licensee MDPI, Basel, Switzerland. This article is an open access article distributed under the terms and conditions of the Creative Commons Attribution (CC BY) license (https:// creativecommons.org/licenses/by/ $4.0 /)$.
1 Plant Sciences Unit, Flanders Research Institute for Agriculture, Fisheries and Food, Burg. Van Gansberghelaan 109, 9820 Merelbeke, Belgium; koen.vanloo@ilvo.vlaanderen.be (K.V.L.); sarah.ommeslag@ilvo.vlaanderen.be (S.O.); siebert.vierendeels@ilvo.vlaanderen.be (S.V.)

2 Flemish Compost and Biogas Association (VLACO), Stationsstraat 110, 2800 Mechelen, Belgium; maxim.rooseleer@vlaco.be (M.R.); elke.vandaele@vlaco.be (E.V.)

* Correspondence: bart.vandecasteele@ilvo.vlaanderen.be

\begin{abstract}
The aim of the current study was to create a high quality growing medium blend that replaces $70 \mathrm{vol} \%$ peat with $40 \mathrm{vol} \%$ woody green compost and $30 \mathrm{vol} \%$ bark compost and organic fertilizers (i.e., blood meal and chitin), all locally sourced. A range of "woody composts", i.e., green composts based on feedstock selection with mainly woody material from tree prunings, were produced for this purpose at green compost facilities. First, the woody composts were characterized chemically and biologically, including their microbial biomass and net $\mathrm{N}$ release. In comparison with regular green composts or vegetable, fruit and garden (VFG) waste composts, woody composts are more suitable for use in growing media due to their lower $\mathrm{pH}$, EC and inorganic $\mathrm{C}$ content; however, the woody compost had a low $\mathrm{N}$ mineralization rate. Three types of composts supported a higher microbial biomass than wood fiber or bark compost. The additional mineral $\mathrm{N}$ release after 100 days for compost mixed with blood meal was tested for different VFG and green composts. A significantly higher additional net $\mathrm{N}$ release was measured for composts with higher initial mineral $\mathrm{N}$ concentrations (317 $\mathrm{mg} \mathrm{N}_{\min } / \mathrm{L}$ ) as well as VFG composts (417 $\mathrm{mg} \mathrm{N}_{\min } / \mathrm{L}$ ) than for green composts with a lower initial mineral $\mathrm{N}$ concentration $\left(148 \mathrm{mg} \mathrm{N}_{\min } / \mathrm{L}\right)$. In a last step, woody compost, bark compost, wood fiber, coir and peat were mixed in different ratios, resulting in six blends ranging from $100 \%$ peat-free to $100 \%$ peat. Two batches of woody compost were compared, and the blends were mixed with blood meal or chitin. A strong effect of both the organic fertilizer and the blend composition on the mineral $\mathrm{N}$ release was observed, with a clear link between the microbial biomass and the net $\mathrm{N}$ release. There was a significant negative correlation between the net change in microbial biomass and the net $\mathrm{N}$ release $(\mathrm{R}=-0.85)$, which implies that a larger increase in microbial biomass during incubation with the organic fertilizer resulted in less $\mathrm{N}$ mineralization. The blends containing woody compost scored better for nitrification activity, as the $\mathrm{NH}_{4}-\mathrm{N}$ concentrations were lower in these than for the blends without woody compost. For the peat blends, no effect on the microbial biomass was observed after addition of organic fertilizers; mineral $\mathrm{N}$ did increase, however. Woody composts have the potential to be used in high vol\% in growing media blends, but the blends still need further optimization when supplemented with organic fertilizers.
\end{abstract}

Keywords: wood fiber; peat replacement; nitrogen mineralization; microbial biomass; peat-free; nitrification; bark; chitin; blood meal

\section{Introduction \\ 1.1. New Materials in Growing Media Blends}

Local materials such as bark, coir products, wood fiber, composts derived from various agricultural residues and vermicompost, used either alone or in combination, have shown 
potential to replace peat as a bulk material [1,2]. Despite the proven benefits of peat as an ingredient for growing media, the environmental impact of peat extraction is important enough to warrant a search for alternatives [2]. Although coir products can be a good technical replacement for peat, its use has also led to serious sustainability concerns [2]. The increasing use of coir products worldwide is also creating uncertainty about whether a sufficient amount of high-quality coir products will remain available for the European market. The alternatives, namely bark and wood fiber, share many of the characteristics of coir and peat, apart from their lower water holding capacity and thus their larger air capacity [3]. When choosing composts, compost-specific characteristics strongly influence their potential as fertilizer [3] or liming agents [4]; their usefulness in growing media as a bulk replacer of peat and/or coir [4]; their capacity for disease suppression [5]; whether they can act as a carrier for biocontrol organisms [6]; and their net $N$ release [7]. Biochar is a relatively new alternative bulk replacement for coir and peat in growing media [3,8,9]. Production methods for wood and other plant fibers based on fiberization can be optimized according to the physical properties of the fibers for the bulk replacement of peat and coir in growing media [10]. These fibers can also affect the microbiological activity and nutrient availability in growing media [11]. By composting chopped fen plant biomass, Hartung and Meinken [12] reported a reduction in the risk of $\mathrm{N}$ immobilization, but also a significant mass reduction. When designing blends containing alternatives for peat and coir, a balance must be struck between the advantages and disadvantages of the alternative materials, with attention given to the effect of compost production methods.

\subsection{The Microbiome of Growing Media}

Besides their different physico-chemical characteristics and nutrient contents, the alternatives for peat and coir may also have specific microbial characteristics in terms of of microbial biomass, microbial activity, microbial diversity and microbial functionality. The microbial communities and related characteristics in growing media depend strongly on the type and composition of the materials in the horticultural substrate [13-15]. New materials in growing media (compost, wood or plant fibers) may support a higher microbial biomass, but they also have a higher microbial activity than peat, which leads to reduced stability $[1,4]$. The use of peat alternatives may require sanitary pre-treatments such as steaming, acidification or the thermal phase during composting to ensure sufficient control of weeds, pathogens and diseases [11,16]. The microbiological activity of substrates is important for stability [4] as well as for the contribution of nitrifying bacteria to nitrification [17] and the control of plant pathogens in the root environment [13]. The positive effects of alternative materials are related to their higher microbial biomass and activity, including the intended acidification of materials or blends with elemental S [4,18], the stimulation of nitrification and the related decrease in $\mathrm{pH}$ [19] and disease suppression [5]. However, the effect of this microbial activity in alternatives for peat and coir is not straightforward, as unwanted effects may occur due to lower stability or $\mathrm{N}$ drawdown. Points of attention include uncontrolled bioactivity in the root zone and the maintenance of initial substrate properties throughout the cultivation cycle [3]. The total microbial biomass (based on phospholipid fatty acids (PLFA) quantification), oxygen uptake rate (OUR) and C mineralization for a range of composts and a range of plant residues from nature conservation management was significantly larger (a difference of up to a factor of five) in comparison to several batches of peat [4]. Feedstock was more important for determining the compost microbiome than the additional treatment of composts via maturation, $\mathrm{S}$ addition, sieving or the blending of the compost with another material [15]. Nevertheless, to a certain degree, blending may be effective in modifying the microbiome [15]. Strong trade-offs may occur between the productivity and disease pressure in a soilless cropping system, as this system is also governed by the microbial composition of the growing media [16]. In conclusion, knowledge of microbial biomass and microbial activity in new growing media blends may help to optimize the composition of the blend, i.e., the choice of materials and their relative proportions. 


\subsection{Interaction between Growing Media and Organic Fertilizers}

The composition of growing media determines the total nutrient content as well as nutrient availability [3]. Composts, vermicomposts and biochars can act as a source of nutrients, but optimal and balanced plant nutrition in growing media requires the addition of extra fertilizer. Organic or mineral fertilizers are either added to the blend or nutrients are provided via fertigation during cultivation. Especially for $\mathrm{N}$, there can be a strong interaction between the $\mathrm{N}$ source and the growing media blend during storage [1] and use [20], as growing media constituents determine the microbial $\mathrm{N}$ conversions in organic growing media for horticulture $[17,21]$. Organic fertilizers have the most complex interaction in terms of predictability and optimization [21]. Organic media carry a saprophytic microbial community that can affect the nutrient status of plants during the growing cycle [20]. To ensure a balanced $\mathrm{N}$ turnover from the growing media and the organic fertilizers, care should be taken when selecting and mixing organic media constituents [20]. The mineralization of organic fertilizers during the storage of growing media may lead to changes in $\mathrm{pH}$ and mineral $N$ concentrations, with subsequent adverse effects on plant growth [1]. Different types of organic fertilizers are characterized by variable $\mathrm{N}$ release rates and elemental compositions, from organic fertilizers with very high $\mathrm{N}$ mineralization to organic fertilizers with a risk of induced $\mathrm{N}$ immobilization [22]. Chitin is an example of an organic fertilizer characterized by high $\mathrm{N}$ mineralization with different functions; besides a substantial $\mathrm{N}$ release of over $50 \%$ of the total $\mathrm{N}$ after 100 days, chitin may also have important effects on the microbiome of growing media $[23,24]$. That microbiome is important in terms of both the rhizosphere and the bulk material, and can result in improved disease suppression [23]; however, it also affects the nitrification process $[17,23,25]$. The presence of reactive functional groups (including amino groups), as well as the polysaccharide nature of chitin and chitosan, allow them to undergo many chemical modifications [26]. Chitosan is a natural amino-polysaccharide derived from chitin, with a good chelating ligand capable of binding to a variety of metal ions [26]. The application of chitin, however, may result in $\mathrm{P}$ and $\mathrm{K}$ imbalances when used in growing media $[23,24]$. Within the range of organic fertilizers, plant-based composts are characterized by a slower $\mathrm{N}$ release than other fertilizers [22,27]. Process conditions during the compost production and the duration of the process also affect the properties of the compost during its application. Specifically, the $\mathrm{N}$ dynamics, i.e., the dynamics of mineralization, nitrification, denitrification, ammonia volatilization and $\mathrm{N}$ cycling through the microbial biomass, can be affected; composts from processes with sub-optimal conditions, i.e., with moisture or $\mathrm{C} / \mathrm{N}$ ratio constraints, can have a higher decomposition activity and thus lower stability, but they may not result in net $\mathrm{N}$ mineralization $[7,28]$. Nitrification determines the $\mathrm{NH}_{4}-\mathrm{N} / \mathrm{NO}_{3}-\mathrm{N}$ ratio of compost and compost-based growing media, and is performed in two steps, carried out by two different groups of microorganisms: ammonia-oxidizing bacteria or archaea (step 1) and the nitrite-oxidizing bacteria (step 2) [29]. Hartz and Giannini [28] observed a trend of decreasing short-term net $\mathrm{N}$ immobilization with increased compost age, while the net $\mathrm{N}$ mineralization in compost-amended soil averaged only $2 \%$ to $3 \%$ of compost total $\mathrm{N}$ content. The differences between plant-based composts with regard to feedstock and production methods for $\mathrm{N}$ dynamics need to be taken into account when these composts are applied in growing media blends.

\subsection{Aim}

Our approach differentiates between compost types in terms of their role in growing media, i.e., composts for bulk use vs. composts used as organic fertilizers. The overall aim of this paper was to test the performance of woody composts, i.e., composts selected for bulk use in growing media blends amended with organic fertilizers, and to assess the interaction between blend composition, organic fertilizers and microbial activity as it affects $\mathrm{N}$ mineralization. The experimental woody composts are dedicated green composts based on specific feedstock selection with mainly woody material from tree prunings. The effect 
of compost type and characteristics on net $\mathrm{N}$ mineralization (step 1) and $\mathrm{N}$ availability after addition of blood meal, as an example of an organic fertilizer, (step 2) was tested.

The target was to provide a high quality growing medium blend with a total of $70 \%$ locally sourced compost (40 vol\% woody compost and $30 \mathrm{vol} \%$ bark compost), amended with two organic fertilizers (chitin or blood meal). Blends with $40 \mathrm{vol} \%$ woody composts with the best fit for use in growing media were made (step 3) and compared with a peatbased blend and a peat-reduced blend without woody compost. This allowed us to test how the composition of the blend can be optimized with organic fertilizers and how this effects $\mathrm{N}$ release and microbial biomass in the growing medium.

\section{Materials and Methods}

\subsection{Characterization of Materials and Blends}

PLFAs were isolated from $0.75 \mathrm{~g}$ freeze-dried material using phosphate buffer, chloroform and methanol at a 0.9:1:2 ratio. Phospholipids separated by solid phase extraction were saponified and then methylated using $0.2 \mathrm{M}$ methanolic $\mathrm{KOH}$ to form fatty acid methyl esters (FAME), which were analyzed using a capillary gas chromatograph-flam ionization detector (Perkin Elmer Clarus 600, Perkin Elmer, Waltham, MA, USA) with a Supelco SP-2560 column. PLFAs were identified by retention time using an external FAME (RESTEK Corporation, Bellefonte, PA, USA) and bacterial acid methyl ester (BAME) mix (Sigma Aldrich, St Louis, MO, USA) and quantified with a C19:0 internal standard. Total microbial biomass was calculated as the sum of 18 PLFAs (i-C15:0, a-C15:0, i-C16:0, i-C17:0, C16:1c9, C17:0cy, C19:0cy, C14:0, C15:0, C16:0, C17:0, C18:0, 10Me-C16:0, 10Me-C18:0, $\mathrm{C} 18: 2 \mathrm{c} 9,12, \mathrm{C} 16: 1 \mathrm{c} 11$ and $\mathrm{C} 18: 1 \mathrm{c} 9)$. To cope with the range of OM contents and bulk density of the different materials, total microbial biomass was expressed per $\mathrm{g} O \mathrm{OM}$.

Three indicators were used in this study for assessing the microbial activity of materials: mineral $\mathrm{N}$ (i.e., $\mathrm{NH}_{4}-\mathrm{N}+\mathrm{NO}_{3}-\mathrm{N}$ ) release, risk of $\mathrm{N}$ immobilization $\left(\mathrm{N}_{\text {immob }}\right)$ and OUR. The materials were tested for immobilization of mineral $\mathrm{N}$ [11] by adding $350 \mathrm{mg} \mathrm{N} / \mathrm{L}$ material followed by incubation at $37^{\circ} \mathrm{C}$ for 7 days. Based on the difference between the theoretical (initial water-extractable mineral $N$ concentration (EN 13652) + added amount of $350 \mathrm{mg}$ N/L material) and actual water-extractable mineral $\mathrm{N}$ content after this incubation period, the $\% \mathrm{~N}$ immobilization was calculated $(100 \% \mathrm{~N}$ immobilization $=350 \mathrm{mg}$ mineral $\mathrm{N} / \mathrm{L}$ material is immobilized).

The net $\mathrm{N}$ mineralization of a material or blend, both a pure blend or one amended with organic fertilizer, was assessed based on a 50 or 100 day-incubation trial (described in detail in the relevant sections below). Briefly, $200 \mathrm{~mL}$ material was placed in a PVC tube $(\mathrm{h}=12 \mathrm{~cm}, \mathrm{r}=2.3 \mathrm{~cm}$ ) based on the bulk density of the material, covered with a single layer of gas permeable Parafilm ${ }^{\circledR}$ and incubated at $15{ }^{\circ} \mathrm{C}$ and $70 \%$ relative humidity. Mineral $\mathrm{N}\left(\mathrm{N}_{\text {min }}\right)$ was extracted after 50 or 100 days of incubation in a 1:5 extraction $(v / v)$, as described below. The net $\mathrm{N}$ mineralization was calculated as the difference in $\mathrm{N}_{\min }$ after 100 days versus the initial $\mathrm{N}_{\text {min }}$ concentration. OUR (expressed as mmol O$/ 2 / \mathrm{kg} \mathrm{OM} / \mathrm{hr}$ ) was measured as the microbial activity in a closed Oxitop respirometer at $20{ }^{\circ} \mathrm{C}$ based on the method reported by Grigatti et al. [30].

The methods for chemical characterization are based on European Standards developed by the CEN, the European Committee for Standardization. European Standard EN numbers refer to the specific standards. $\mathrm{EC}, \mathrm{pH}_{(\mathrm{H} 2 \mathrm{O})}$ and $\mathrm{Cl}, \mathrm{SO}_{4}, \mathrm{P}$ and mineral $\mathrm{N}$ of growing media were measured in a 1:5 v/v water extract according to EN 13038, EN 13037 and EN 13652, respectively. Extracts were analyzed for $\mathrm{Cl}, \mathrm{SO}_{4}, \mathrm{P}$ and $\mathrm{NO}_{3}-\mathrm{N}$ with a Dionex ICS-3000 ion chromatograph (Dionex, Sunnyvale, CA, USA), and $\mathrm{NH}_{4}-\mathrm{N}$ was measured with a Skalar San ++ continuous flow analyzer (Skalar, Breda, The Netherlands). K and $\mathrm{P}$ were extracted $(1: 5 \mathrm{v} / \mathrm{v})$ in $0.5 \mathrm{M}$ ammonium acetate (AmAc) buffered at $\mathrm{pH} 4.65$ (with a $96 \%$ acetic acid) to assess the $\mathrm{K}$ and $\mathrm{P}$ concentrations being potentially plant-available in the growing medium in the longer term. The $\mathrm{K}$ and $\mathrm{P}$ concentration in the extract was measured with a 5110 VDV Agilent ICP-OES (Agilent, Santa Clara, CA, USA). 
Sample preparation for determination of total nutrient content, dry matter content, moisture content and laboratory compacted bulk density was executed according to EN 13040. The dry bulk density was calculated based on the moisture content of the material. The total porosity, air filled porosity and water filled porosity at $-10 \mathrm{~cm},-50 \mathrm{~cm}$ and $-100 \mathrm{~cm}$ (as an indicator of water holding capacity) was determined according to EN 13041. Samples were dried for 4 days at $70{ }^{\circ} \mathrm{C}$ then mechanically ground in a cross beater mill equipped with heavy-metal-free grinding tools (SK100, Retsch, Haan, Germany). Ground samples were stored in closed PP containers before analysis. Determination of OM content was done according EN 13039 by ashing in a Heraeus muffle oven at $550{ }^{\circ} \mathrm{C}$. Total $\mathrm{N}$ concentration (determined according to the Dumas method, EN 13654-2), total C and inorganic C (IC) were measured using a Skalar Primacs SNC 100 analyzer (Skalar, The Netherlands). Based on total $\mathrm{C}$ and total $\mathrm{N}$, the $\mathrm{C} / \mathrm{N}$ ratio of the materials was calculated.

\subsection{Microbial Biomass and Activity and Net N Release of Composts versus Wood Fiber and Bark}

Different types of composts were compared, with each type of compost being based on a specific feedstock and composting process. VFG composts are produced in indoor licensed confined facilities with more intensive process monitoring (turning and/or forced aeration) than for open air facilities, and in some cases in combination with anaerobic pre-digestion. The input materials are separately collected organic household waste, i.e., garden waste and kitchen waste. Green composts are produced in licensed open air facilities based on separately collected green waste and with regular turning or forced aeration based on process monitoring. For woody composts, a specific feedstock of tree prunings is composted in open air compost facilities, with the process requiring more water, lower process temperatures and a longer process duration in comparison to green waste composting. In terms of the composting process, the 'woody composts' can thus be considered a subgroup of the green composts. Bark compost is mostly produced in a static pile set-up in open air where tree bark is mixed with mineral or organic $\mathrm{N}$ sources, and the mixture is moistened during processing when needed. For compost based on spent growing media, a specific feedstock of spent growing media is co-composted in open air compost facilities, in a very similar fashion to green waste composting. Five batches of woody compost were compared with three batches of VFG compost, six batches of green compost, five batches of wood fiber and five batches of bark compost based on one-way ANOVA and the Scheffé multiple comparison post-hoc test (Statistica 13.5, Statsoft Inc., Hamburg, Germany). Homogeneity of variances was checked using box plots and data normality was checked using QQplots. To obtain data normality and homogeneity of variances, square root-transformation (P-AmAc, K-AmAc, OUR, dry bulk density) or $\log 10$ transformation (EC, total microbial biomass, $\mathrm{C} / \mathrm{N}, \mathrm{N}_{\min }$ ) were used.

For 15 composts, the net $\mathrm{N}$ mineralization was assessed based on a 100 day-incubation trial, as described above. Each compost was thoroughly mixed and incubated with three replicates per compost. If needed, composts were moistened at the start of the incubation to reach a moisture content of $21 \mathrm{vol} \%$ (or on average $26 \%$ water-filled pore space). Pearson correlation coefficients were calculated among compost characteristics.

A simple scoring system based on chemical or stability characteristics was applied to assess the suitability of these materials to replace peat, lime (i.e., inorganic C) and fertilizers in growing media blends [4]. Materials were scored based on eight characteristics ( $\mathrm{pH}, \mathrm{EC}$, OM, OUR, dry bulk density, inorganic $C$ content and $\mathrm{N}_{\text {immob }}$ ) to assess their fit with the expected characteristics for use in growing media. Each characteristic was assigned a score of 2 (most suitable), 1 or 0 (least suitable). Summing these scores results in a maximum score of 16 , the greatest suitability of a material for use in growing media blends. Three scores were based on the upper limits for organic matter and electrical conductivity or the $\mathrm{pH}$ range set for growing media by the Belgian government. For stability, the legal criterion for OUR in compost was used. The inorganic $C$ content, the dry bulk density and the risk 
for $\mathrm{N}$ immobilization were included as well. The last score was related to the fertilizer replacement value of the material and was based on Ammonium Acetate-extractable P.

\subsection{Net $N$ Release from Composts Blended with Blood Meal}

In this step, the effect of compost type and initial mineral $\mathrm{N}$ concentration were evaluated according to net $\mathrm{N}$ release of pure composts and composts amended with blood meal. The $\mathrm{N}$ release for a set of 36 composts (10 VFG composts and 26 green composts) after 100 days was assessed as described above, with the exception that each mixture was tested with one replicate only (one replicate for each pure compost and one replicate for each compost mixed with $3.5 \mathrm{~g}$ blood meal/L compost) (13-0-0, Orgamé, Belgium). When needed, composts were moistened at the start of the incubation to reach a moisture content of $22.5 \mathrm{vol} \%$ (or on average $30 \%$ water-filled pore space). Each compost was initially analyzed for OUR, PLFA and mineral $\mathrm{N}$ content. The green composts were divided in two subgroups based on initial mineral $\mathrm{N}$ concentration: low ( $<10 \mathrm{mg} \mathrm{N} / \mathrm{L}$ compost) or high (>10 mg N/L compost). The total microbial biomass and net $\mathrm{N}$ release for three groups of compost (10 VFG composts, 12 green composts with high initial mineral $\mathrm{N}$ concentrations and 14 green composts with an initially low mineral $\mathrm{N}$ concentration) were compared with one-way ANOVA and the Scheffé multiple comparison post-hoc test.

\subsection{Effect of Blend and Organic Fertilizer on N Release}

The added value of woody compost in blends with $70 \mathrm{vol} \%$ peat replacement was assessed. For two woody composts, a growing medium blend with 40 vol $\%$ woody compost, $30 \mathrm{vol} \%$ bark compost from Scotch pine (Pinus sylvestris) and $30 \mathrm{vol} \%$ peat (a mixture of white and black peat) was made (mixtures M1 and M2). These blends were compared with (a) peat-free blends with the same composition except that the peat was replaced with $30 \mathrm{vol} \%$ wood fiber (Mixture M3 and M4), (b) the $40 \mathrm{vol} \%$ woody compost was replaced by $20 \mathrm{vol} \%$ wood fiber and $20 \mathrm{vol} \%$ coir fiber (Mixture M5) and (c) a peat blend of $50 \mathrm{vol} \%$ white peat and 50 vol\% black peat (Mixture M0). To reach an optimal pH, $1.4 \mathrm{~g} / \mathrm{L}$ lime was added to the peat blend. For the peat-free blends, the addition of elemental $S$ was needed to lower the $\mathrm{pH}$.

For these six blends, the $\mathrm{N}$ mineralization rate after 50 and 100 days was assessed after the addition of $3.5 \mathrm{~g}$ blood meal or $2 \mathrm{~g}$ chitin per $\mathrm{L}$ as a $\mathrm{N}$ source. Commercially available chitin (from crab shells) from Biolog Heppe ${ }^{\circledR}$, (Landsberg, Germany) was used, based on previous publications (e.g., [23]). Blends were moistened to reach a moisture content of $30 \mathrm{vol} \%$ (or on average $30 \%$ water-filled pore space) and then pre-incubated for 2 weeks at $15{ }^{\circ} \mathrm{C}$. The total mineral $\mathrm{N}$ concentration $\left(=\mathrm{NO}_{3}-\mathrm{N}+\mathrm{NH}_{4}-\mathrm{N}\right)$ for these treatments after 50 and 100 days was assessed as described above, and each mixture was tested in three replicates. PLFA was measured for the initial blends without organic fertilizers after pre-incubation and for the blends with organic fertilizers after 100 days of incubation.

Mineral $\mathrm{N}$ concentrations were first compared for the six blends and the two organic fertilizers after incubation for 50 and 100 days with ANOVA. Due to the interaction between organic fertilizer type and time point, the total mineral $\mathrm{N}$ concentration $\left(=\mathrm{NO}_{3}-\mathrm{N}+\mathrm{NH}_{4}-\mathrm{N}\right)$ after incubation for 50 or 100 days was compared between the blends per organic fertilizer type and per time point with one-way ANOVA and Tukey HSD multiple comparison post-hoc test.

For each combination of the six blends and the three levels of fertilizer addition (i.e., two organic fertilizers versus the unfertilized blends), four pots were filled with $200 \mathrm{~mL}$ of the blend and three cucumber seeds (Marketmore Bio, AVEVE, Belgium) were sown per pot at a depth of $0.5 \mathrm{~cm}$ on 31 May 2021 and grown at room temperature using a natural light regime. The blends were stored for at least 100 days at $15^{\circ} \mathrm{C}$ after addition of chitin or blood meal previous to the seed test. Water was supplied in a dish underneath the pots. The trial with 72 pots ended on 25 June 2021. The number of emerged seeds was counted twice a week. The \% emergence was compared using two-way ANOVA for blend composition and for fertilizer type (unfertilized, blood meal or chitin). 


\section{Results}

\subsection{Step 1: Microbial Biomass and Activity and Net N Release of Composts versus Wood Fiber and Bark}

The VFG, green and woody composts were characterized by lower OM content and higher $\mathrm{pH}, \mathrm{EC}, \mathrm{IC}$, plant-available $\mathrm{P}$ and $\mathrm{K}$, and microbial biomass than the wood fiber or bark composts (Table 1). No significant differences were observed for $\mathrm{N}_{\mathrm{immob}}$, and OUR values were only significantly higher for the woody composts than for the wood fibers. The $\mathrm{N}_{\text {min }}$ concentrations in the wood fibers were below $10 \mathrm{mg} \mathrm{N} / \mathrm{L}$. The $\mathrm{N}_{\min }$ concentration in the bark composts (10-20 mg N/L) and woody composts (10-80 mg N/L) were significantly lower $(p=0.0004)$ than for the VFG composts $(250-1070 \mathrm{mg} \mathrm{N} / \mathrm{L})$, with intermediate values for the green composts (10-230 mg N/L). There was a clear differentiation in the range of the suitability scores for use in growing media between VFG compost (5-9), green compost (5-10), bark compost (11-14), wood fiber (9-13) and woody compost (9-10). In summary, there were no significant differences in characteristics between the woody composts, VFG composts or green composts except for the lower $\mathrm{N}_{\min }$ concentrations in the woody composts versus the VFG composts, while the scores for use in growing media for the woody composts were in the higher range compared with the other two types of compost. Within one type of compost, there was a high variability between compost batches for some characteristics.

The net $\mathrm{N}$ release after 100 days was measured for 15 composts including 3 VFG composts, 6 green composts and 5 woody composts (Table 2). Composts with a score above 10 were characterized by low net $\mathrm{N}$ release rates, with net $\mathrm{N}$ mineralization after 100 days being lower than $50 \mathrm{mg}$ N/L compost, while composts with a score below 10 had a higher range of $\mathrm{N}$ release (Table 2). The score can be used to assess the volume rates for incorporating a material into the blend, with higher scores indicating higher volume rates. A significant negative correlation was observed between the score and the \% inorganic $\mathrm{C}(\mathrm{r}=-0.755)$, EC $(\mathrm{r}=-0.594)$ and plant-available $\mathrm{P}(\mathrm{r}=-0.687)$ and $\mathrm{K}(\mathrm{r}=-0.758)$. This correlation indicates that nutrient-rich composts with a higher $\mathrm{N}$ release capacity can theoretically be used in growing media, but the high IC, $\mathrm{pH}$ and EC restrict the use of these composts in higher volume rates. In contrast, composts with lower values for $\mathrm{pH}, \mathrm{EC}$ and IC have more potential to be used as bulk material in growing media. There was no significant correlation between the net $\mathrm{N}$ release rate and the OUR $(\mathrm{r}=0.02)$ or the total microbial biomass $(\mathrm{r}=0.02)$. There was also no significant correlation between total microbial biomass and OUR $(r=0.23)$ or $\mathrm{N}_{\text {immob }}(\mathrm{r}=-0.25)$. Total microbial biomass was thus not correlated with the measurements of microbial activity (OUR, $\mathrm{N}_{\mathrm{immob}}$, net $\mathrm{N}$ mineralization) in the composts.

No significant correlation was observed between $\mathrm{C} / \mathrm{N}$ and OUR, so $\mathrm{C} / \mathrm{N}$ was not found to be a stability indicator as previously suggested [1]. For the link between $\mathrm{C} / \mathrm{N}$ and net $\mathrm{N}$ release, two groups were observed: the five composts with a net $\mathrm{N}$ release higher than $50 \mathrm{mg} \mathrm{N} / \mathrm{L}$ had a $\mathrm{C} / \mathrm{N}$ ratio below 11, while the composts with a net $\mathrm{N}$ release of $50 \mathrm{mg} \mathrm{N} / \mathrm{L}$ or lower had a C/N ratio between 11 and 29. The net $\mathrm{N}$ release (after square root transformation) after 100 days was compared with one-way ANOVA for the VFG composts, green composts and woody composts; no statistical differences were observed $(p=0.236)$. 
Table 1. Chemical and microbial characteristics of VFG, green, wood and bark composts versus wood fibers (VFG: vegetable, fruit and garden waste compost, IC: inorganic C, EC: electrical conductivity, $\mathrm{N}_{\text {min }}$ : mineral $\mathrm{N}$ concentration $\left(=\mathrm{NO}_{3}-\mathrm{N}+\mathrm{NH}_{4}-\mathrm{N}\right), \mathrm{N}_{\text {immob}}$ \% $\mathrm{N}$ immobilization, P-AmAc and K-AmAc: plant-available P and K resp., OM: organic matter, OUR: oxygen uptake rate, total biomass: total microbial biomass based on PLFA). Different letters indicate the significant differences as found by the Scheffé post-hoc test.

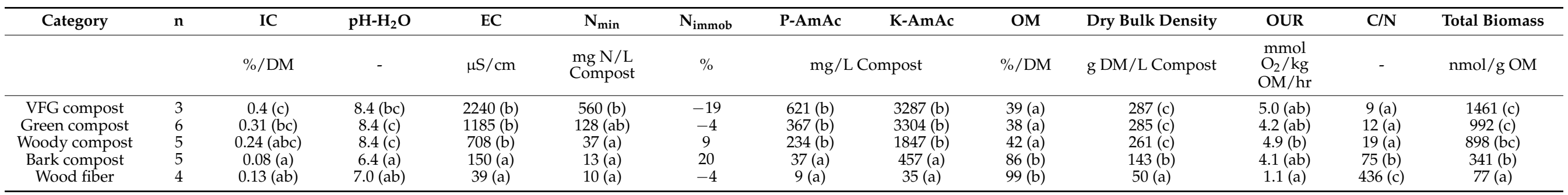

Table 2. Net $\mathrm{N}$ release (after 100 days of incubation at $15{ }^{\circ} \mathrm{C}$ and $70 \%$ rel. humidity), suitability score for use in growing media and chemical and biological characteristics for 15 composts, including 5 woody composts, and the bark compost and wood fiber used in the growing media blends (SGM: spent growing media, VFG: vegetable, fruit and garden waste compost, IC: inorganic C, EC: electrical conductivity, $\mathrm{N}_{\min }$ : mineral $\mathrm{N}$ concentration $\left(=\mathrm{NO}_{3}-\mathrm{N}+\mathrm{NH}_{4}-\mathrm{N}\right), \mathrm{N}_{\text {immob}}$ : \% $\mathrm{N}$ immobilization, $\mathrm{P}-\mathrm{AmAc}$ and K-AmAc: plant-available P and K resp., OM: organic matter, OUR: oxygen uptake rate, total biomass: total microbial biomass based on PLFA, NA: not assessed).

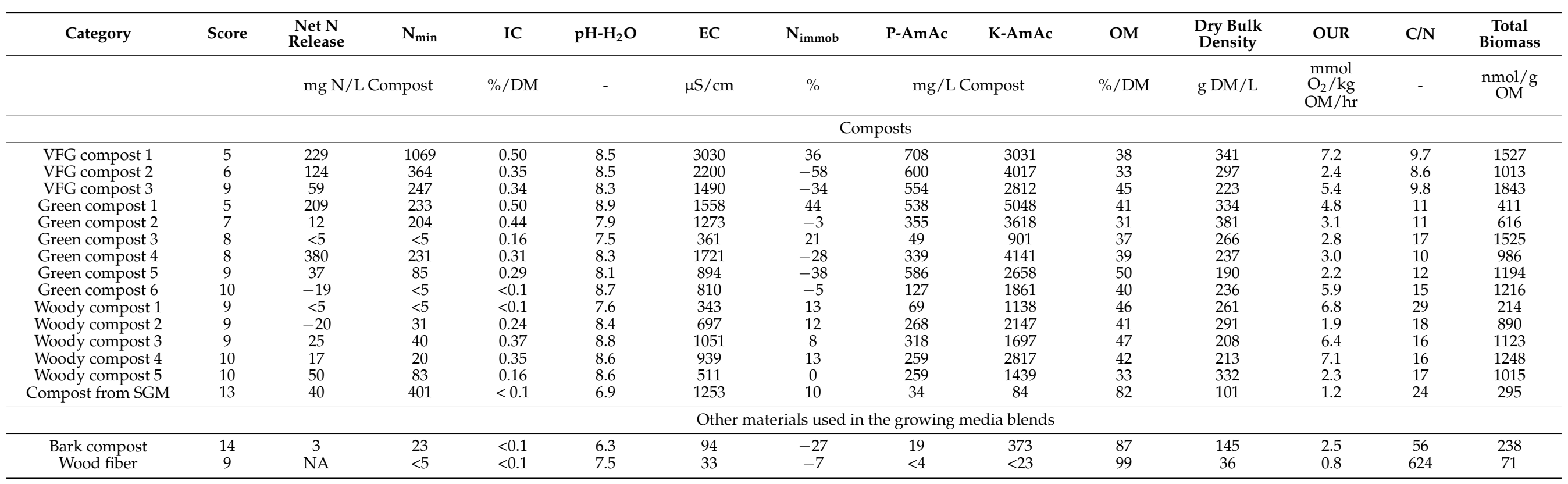




\subsection{Step 2: Net N Release from Composts Blended with Blood Meal}

The VFG composts initially had higher $\mathrm{N}_{\min }$ concentrations than the green composts, and the range of $\mathrm{NH}_{4}-\mathrm{N}$ was also higher for the VFG composts, although some VFG composts did not contain detectable amounts of $\mathrm{NH}_{4}-\mathrm{N}$. A significant difference $(p=0.035)$ was found for the total microbial biomass as expressed on an OM basis, with a significantly lower biomass observed only for the green composts with initial low $\mathrm{N}_{\min }$ concentrations $(682 \mathrm{nmol} / \mathrm{g} \mathrm{OM})$ in comparison to the VFG composts $(1210 \mathrm{nmol} / \mathrm{g} \mathrm{OM})$ and with an intermediate value for the group of green composts with initial high $\mathrm{N}_{\min }$ concentrations (817 nmol/g OM) (Figure 1a).
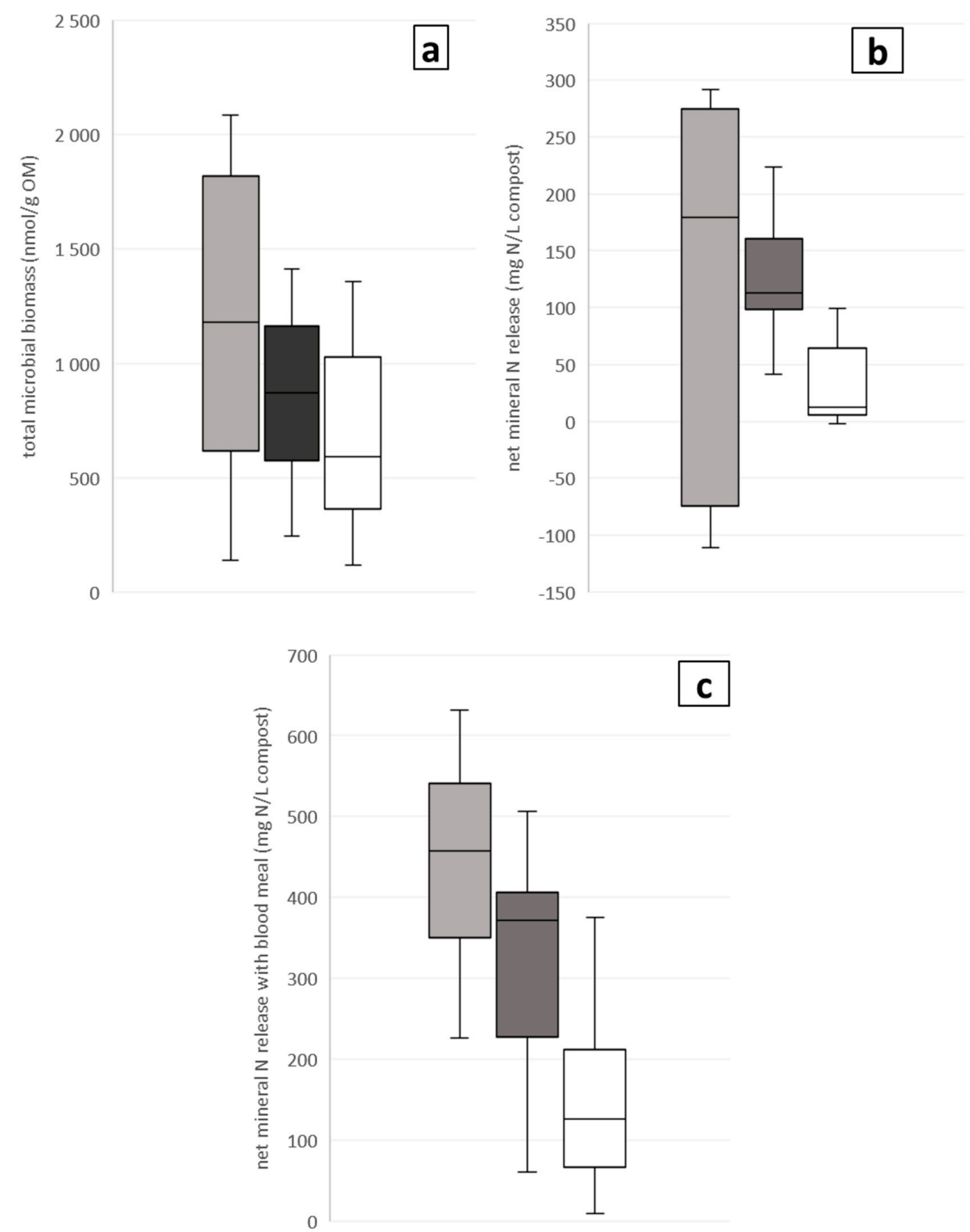

Figure 1. Total microbial biomass expressed on an OM basis (a), net mineral $\mathrm{N}$ release after 100 days of incubation for the composts without organic fertilizer (b) and the net mineral $\mathrm{N}$ release after 100 days for the composts with blood meal (c) for vegetable, fruit and garden waste (VFG) compost (light grey), green composts with higher initial mineral $\mathrm{N}$ concentrations ("Green compost, $\mathrm{N}_{\min }$ high", dark grey box) and green composts with a lower initial mineral N concentration ("Green compost, $\mathrm{N}_{\min }$ low", white box). 
No differences were observed in terms of the net mineral $\mathrm{N}$ release during 100 days for the pure composts $(p=0.03$, but no significant differences between the three groups were detected by Scheffé's multiple comparison). The net mineral $\mathrm{N}$ release of the composts without organic fertilizers had a higher range for the VFG composts than for the green composts (Figure $1 \mathrm{~b}$ ). Two groups can be observed for the net mineral $\mathrm{N}$ release in the VFG composts: a group with a positive net $\mathrm{N}$ release versus a group with a negative net $\mathrm{N}$ release (the mineral $\mathrm{N}$ initially present is immobilized during incubation). There is no direct link between this observation and the microbial biomass or other properties, however. The green composts are only characterized by net $\mathrm{N}$ release (Figure $1 \mathrm{~b}$ ).

For almost all composts, the addition of blood meal resulted in the additional net release of mineral $\mathrm{N}$, with the amount of $\mathrm{N}$ released being dependent on the compost type and initial $\mathrm{N}_{\text {min }}$ concentration (Figure 1c. A clear and significantly higher net $\mathrm{N}$ release was observed for composts with higher initial $\mathrm{N}_{\min }$ concentrations (net release of $317 \mathrm{mg} \mathrm{N}_{\min } / \mathrm{L}$ ) as well as the VFG composts (net release of $417 \mathrm{mg} \mathrm{N}_{\min } / \mathrm{L}$ ) in comparison to the green composts, which had a lower initial $\mathrm{N}_{\min }$ concentration (net release of $\left.148 \mathrm{mg} \mathrm{N}_{\min } / \mathrm{L}\right)(p<0.001)$.

In conclusion, green composts with lower initial $\mathrm{N}_{\min }$ concentrations have a lower additional $\mathrm{N}$ release after blending with an organic fertilizer with a fast $\mathrm{N}$ release (blood meal). The woody composts are considered here as a subcategory of green composts.

\subsection{Step 3: Effect of Blend and Organic Fertilizer on N Release}

\subsubsection{Characteristics of the Materials and the Blends}

The different woody composts in this study had a similar score for use in growing media (between 9 and 10). Two woody composts were selected for use in growing media blends, and were combined with black and white peat, wood fiber, bark compost and/or coir, all in different ratios (Table 3). Woody compost 1 had a high $\mathrm{C} / \mathrm{N}$ ratio of 29 , low total microbial biomass (214 $\mathrm{nmol} / \mathrm{g} \mathrm{OM}$ ) and a higher OUR of $7 \mathrm{mmol} \mathrm{O} / \mathrm{kg} \mathrm{OM} / \mathrm{hr}$ than woody compost 2, while woody compost 2 had a lower $\mathrm{C} / \mathrm{N}$ ratio of 18 , a higher microbial biomass (890 nmol/g OM) and a lower OUR of $2 \mathrm{mmol} \mathrm{O}_{2} / \mathrm{kg} \mathrm{OM} / \mathrm{hr}$ (Table 2). The characteristics of the woody composts, bark compost and wood fiber used in the blends are given in Table 2. The bark and woody composts and the wood fiber were characterized by low $\mathrm{N}_{\text {immob }}(<15 \%)$ but also by a low net $\mathrm{N}$ release $(<20 \mathrm{mg} \mathrm{N} / \mathrm{L}$ after 100 days). In agreement with the observations in Table 1, the wood fiber had a lower microbial biomass (Table 2).

The blend composition, chemical characteristics and the total $\mathrm{N}_{\text {min }}$ concentration before and after incubation are reported in Table 3. Blends M2 and M4 had higher plantavailable nutrient concentrations than the other blends, reflecting the higher plant-available nutrient concentrations in woody compost 2 compared to woody compost 1 , wood fiber or bark composts (Table 4). The peat-free blends (M3, M4) were characterized by a higher air volume at $-10 \mathrm{~cm}$ and a lower volume of easily available water than the peat-reduced blends (M1, M2) (Table 4). Based on the $\mathrm{pH}$ and the other chemical characteristics of the blends, there was only a need to acidify the 2 peat-free blends (M3, M4) with elemental S. A dose of 0.5 and $1.0 \mathrm{~g} \mathrm{~S} / \mathrm{L}$ for M3 and M4, respectively, was sufficient to reach a $\mathrm{pH}$ in the optimal range of 4.5-7.0. For $\mathrm{M} 3$, this resulted in a $\mathrm{pH}$ of 6.9 and an EC of $454 \mu \mathrm{S} / \mathrm{cm}$, and for $\mathrm{M} 4$, it resulted in a $\mathrm{pH}$ of 5.4 and an EC of $1157 \mu \mathrm{S} / \mathrm{cm}$. 
Table 3. Composition and chemical characteristics of the blends, total mineral $\mathrm{N}$ concentration $\left(=\mathrm{NO}_{3}-\mathrm{N}+\mathrm{NH}_{4}-\mathrm{N}, \mathrm{mg} \mathrm{N} / \mathrm{L}\right.$ substrate) after 50,100 and 250 days of incubation at $15{ }^{\circ} \mathrm{C}$ and $70 \%$ rel. humidity) and total microbial biomass for the initial unfertilized blends versus the blends with blood meal or chitin after 100 days of incubation. Differences between the blends after incubation were assessed per organic fertilizer type and for 50 and 100 days of incubation separately due to interaction. Different letters indicate the significant differences as found by Tukey's HSD post-hoc test (M: mixture). Letters in italics were statistics performed per fertilizer and per time point.

\begin{tabular}{|c|c|c|c|c|c|c|}
\hline & M1 & M2 & M3 & M4 & M5 & M0 \\
\hline \multicolumn{7}{|c|}{ Composition } \\
\hline Woody compost 1 (vol\%) & 40 & & 40 & & & \\
\hline Woody compost $2(\mathrm{vol} \%)$ & & 40 & & 40 & & \\
\hline Black peat (vol\%) & 15 & 15 & & & 15 & 50 \\
\hline White peat (vol\%) & 15 & 15 & & & 15 & 50 \\
\hline Bark compost (vol\%) & 30 & 30 & 30 & 30 & 30 & \\
\hline Wood Fiber (vol\%) & & & 30 & 30 & 20 & \\
\hline Coir fiber (vol\%) & & & & & 20 & \\
\hline Lime $(\mathrm{g} / \mathrm{L})$ & 0 & 0 & 0 & 0 & 0 & 1.4 \\
\hline Elemental S (g/L) & 0 & 0 & 0.5 & 1.0 & 0 & 0 \\
\hline \multicolumn{7}{|c|}{ Initial mineral $\mathrm{N}$} \\
\hline Without fertilizer & 11 & 59 & 10 & 18 & 25 & $<5$ \\
\hline \multicolumn{7}{|c|}{ Total mineral $\mathrm{N}$ after 50 day incubation at $15^{\circ} \mathrm{C}(\mathrm{n}=3)$} \\
\hline Blood meal (3.5 g/L) & 11 (a) & $40(b)$ & 10 (a) & $11(\mathrm{a})$ & 15 (a) & $30(b)$ \\
\hline Chitin $(2 \mathrm{~g} / \mathrm{L})$ & $29(\mathrm{~B})$ & $92(\mathrm{D})$ & $9(\mathrm{~A})$ & $64(\mathrm{C})$ & $21(\mathrm{~B})$ & $26(\mathrm{~B})$ \\
\hline \multicolumn{7}{|c|}{ Total mineral $\mathrm{N}$ after 100 day incubation at $15^{\circ} \mathrm{C}(\mathrm{n}=3)$} \\
\hline Blood meal $(3.5 \mathrm{~g} / \mathrm{L})$ & $9(a)$ & $57(c)$ & $9(a)$ & $10(a)$ & $32(b)$ & $95(d)$ \\
\hline Chitin $(2 \mathrm{~g} / \mathrm{L})$ & $27(B)$ & $119(D)$ & $8(A)$ & $96(C)$ & $26(B)$ & $43(B)$ \\
\hline \multicolumn{7}{|c|}{ Total mineral $\mathrm{N}$ after 250 day incubation at $15^{\circ} \mathrm{C}(\mathrm{n}=1)$} \\
\hline Chitin (2 g/L) & 42 & 170 & 7 & 142 & 41 & 106 \\
\hline \multicolumn{7}{|c|}{ Microbial biomass (nmol/g OM) $(\mathrm{n}=1)$} \\
\hline Without fertilizer & 265 & 346 & 457 & 574 & 228 & 150 \\
\hline Blood meal (3.5 g/L) & 452 & 457 & 639 & 907 & 357 & 149 \\
\hline Chitin (2 g/L) & 374 & 305 & 699 & 439 & 363 & 140 \\
\hline
\end{tabular}

Table 4. Chemical and physical characteristics of the blends without organic fertilizers (DM: dry matter, EC: electrical conductivity, mineral $\mathrm{N}$ concentration $\left.=\mathrm{NO}_{3}-\mathrm{N}+\mathrm{NH}_{4}-\mathrm{N}\right), \mathrm{P}-\mathrm{AmAc}$ and K-AmAc: plant-available P and K resp., N.A.: not assessed).

\begin{tabular}{|c|c|c|c|c|c|c|}
\hline & & M1 & M2 & M3 & M4 & M5 \\
\hline $\mathrm{pH}-\mathrm{H}_{2} \mathrm{O}$ & - & 6.7 & 6.5 & 7.4 & 7.3 & 5.5 \\
\hline EC & $\mu S / \mathrm{cm}$ & 174 & 380 & 225 & 403 & 95 \\
\hline Mineral N & $\mathrm{mg} / \mathrm{L}$ substrate & $<10$ & 25 & $<10$ & $<10$ & 20 \\
\hline P-AmAc & & 35 & 126 & 47 & 156 & $<14$ \\
\hline $\mathrm{K}-\mathrm{AmAc}$ & & 578 & 1064 & 701 & 1256 & 158 \\
\hline Dry bulk density & g/L dry substrate & 227 & 237 & 203 & 226 & NA \\
\hline Total pore volume & volume $\%$ & 88 & 87 & 89 & 88 & NA \\
\hline Air volume $-10 \mathrm{~cm}$ & & 16 & 17 & 39 & 34 & NA \\
\hline Air volume $-50 \mathrm{~cm}$ & & 44 & 47 & 57 & 55 & NA \\
\hline Air volume $-100 \mathrm{~cm}$ & & 50 & 52 & 61 & 59 & NA \\
\hline Water volume $-10 \mathrm{~cm}$ & & 71 & 70 & 50 & 54 & NA \\
\hline Water volume $-50 \mathrm{~cm}$ & & 43 & 41 & 32 & 33 & NA \\
\hline Water volume $-100 \mathrm{~cm}$ & & 38 & 35 & 28 & 30 & NA \\
\hline Easily available water & & 28 & 29 & 19 & 21 & NA \\
\hline Organic matter & $\% / \mathrm{DM}$ & 61 & 60 & 63 & 57 & 90 \\
\hline
\end{tabular}

\subsubsection{Total Mineral N Concentrations and Microbial Biomass}

The total $\mathrm{N}_{\min }$ concentration after incubation (sum of the initial mineral $\mathrm{N}$ and the net $\mathrm{N}$ release during incubation) represents the amount of mineral $\mathrm{N}$ which is available for plants after 50 or 100 days in the growing medium blend. The observed statistical interaction between organic fertilizer type and time point indicates that the total mineral $\mathrm{N}$ in the blends was determined by both the organic fertilizer type and the duration of the incubation in a blend-specific manner. Due to this interaction, the results were compared 
per organic fertilizer type and duration of the incubation separately. A $\mathrm{N}$ release of approx. 40 and $100 \mathrm{mg} \mathrm{N} / \mathrm{L}$ substrate was measured in the peat blend 100 days after chitin or blood meal amendment, respectively. For the other blends, chitin resulted in a higher $\mathrm{N}$ release than blood meal for M2 and M4, and to a lesser extent, for M1. For blend M3, no net N release was observed for both tested fertilizers. For M5, the peat-reduced blend without woody compost, none of the organic fertilizers resulted in an increase in the mineral $\mathrm{N}$ concentration. As such, the low $\mathrm{N}$ release in the peat-reduced blends was not exclusively limited to the blends with woody compost. For the blends with net $\mathrm{N}$ release after the use of the organic fertilizer, the $\mathrm{N}$ release was lower after 50 days than after 100 days.

Although some blends initially already contained some mineral N (i.e., the M2, M4 and M5 blends), the measured amount of mineral $\mathrm{N}$ after 100 days was lower than for the peat blend, indicating that the mineral $\mathrm{N}$ released by the blood meal was either immobilized again or that the $\mathrm{N}$ mineralization was lower for these blends. This was the case for M1, M3 and M5, i.e., the peat-reduced blends with woody compost 1 or without compost.

Both chitin and blood meal resulted in an increase in the microbial biomass of all the blends except for the peat blend. The microbial biomass in $100 \%$ peat was not affected by the addition of fertilizer, although a net $\mathrm{N}$ release of 40 to $100 \mathrm{mg} \mathrm{N} / \mathrm{L}$ was observed. This net $\mathrm{N}$ release was the result of the microbial decomposition of the organic fertilizers, but the microbial activity did not result in an increase in microbial biomass in peat. For the other blends, blood meal amendment resulted in an increase in the microbial biomass of the M1, M2, M3, M4 and M5 blends, while the addition of chitin only resulted in an increase for M1, M3 and M5, i.e., the three blends where no net increase in mineral $\mathrm{N}$ after chitin addition was observed. Although no microbial activity in terms of $\mathrm{N}$ release was observed in some of the blends, an increase in microbial biomass for these blends was detected.

There was a significant negative correlation between the net change in microbial biomass during incubation with the organic fertilizer and the net $\mathrm{N}$ release $(\mathrm{R}=-0.85$, $p<0.05, \mathrm{n}=12$ ), which implies that a larger increase in microbial biomass during incubation with the organic fertilizer resulted in less $\mathrm{N}$ mineralization.

\subsubsection{Plant Trial with Cucumber: Seed Emergence}

The average $\%$ of seed emergence was high, with values between $83 \%$ and $100 \%$ emergence after 2 weeks. There was no interaction between the blend and the fertilizer applied $(p=0.64)$, and the number of emerged seeds was not significantly affected by blend $(p=0.11)$ nor fertilizer $(p=0.06)$.

In conclusion, replacing peat with woody compost to a high degree in blends with organic fertilizers is challenging. A strong effect on the mineral $\mathrm{N}$ release was observed as a result of both the organic fertilizer and the blend composition. For the blends tested, there was a clear link between the increase in microbial biomass and the net $\mathrm{N}$ release after the addition of an organic fertilizer. The best results in terms of total mineral $\mathrm{N}$ were obtained with the blends with woody compost 2 (the compost with the higher microbial biomass, and lower $\mathrm{C} / \mathrm{N}$ ratio and OUR) amended with chitin. No effect was observed on seed emergence for cucumber with respect to blend or fertilizer regime.

\section{Discussion}

Composts with the best fit for use as peat replacement in growing media were selected and blends with these composts were optimized with the aim of increasing sustainability of soilless plant production. The partial or complete replacement of peat by compost in growing media may affect the fate of mineral $\mathrm{N}$ released from the fertilizers. The replacement of chemical fertilizers by organic fertilizers may also increase the sustainability of growing media [31]. Organic fertilizers depend on microbial decomposition activity for $\mathrm{N}$ mineralization, mostly resulting in a lower predictability with respect to the mineral $\mathrm{N}$ availability in comparison to the use of chemical fertilizers [21]. The correct prediction of biological processes, including the $\mathrm{N}$ related processes in growing media, is a major 
challenge for the horticulture industry [1]. Within the current study we aimed to answer the following questions:

- What is the $\mathrm{N}$ release of composts selected for a better fit for use in growing media, both for the composts with or without added organic fertilizers?

- $\quad$ Can the blend with woody compost be optimized with organic fertilizers to increase the mineral $\mathrm{N}$ availability? What is the interaction between $\mathrm{N}$ release and microbial biomass?

\subsection{Compost: Role as Bulk Material vs. Role as Organic Fertilizer}

When compost is used primarily as a bulk replacement for peat or coir in horticultural substrates, selecting composts with optimal characteristics is key to the quality of the growing medium [4]. Merely replacing peat or coir with composts characterized by a high fertilizer and/or lime replacement capacity may jeopardize the quality of the growing medium if the liming or the fertilizer addition in the blend is not adapted, as this can lead to $\mathrm{EC}$ or $\mathrm{pH}$ values that either extend beyond the optimal range or to unbalanced nutrient dosing. In growing media, the type of compost is closely related to how much of it is included. Woody green composts have a higher potential to be used for bulk replacement of peat and coir in growing media, while more nutrient-rich composts with a higher inorganic $\mathrm{C}$ content and a higher $\mathrm{N}$ release (i.e., VFG composts) should be used in lower doses, as they mainly act as organic fertilizer rather than as bulk replacement. These two types of compost can be combined in one blend, with a specific role for each compost.

Woody composts are produced from a feedstock of selectively collected tree prunings. Despite achieving higher scores for use in growing media than VFG and green composts, woody composts may be characterized by lower initial mineral $\mathrm{N}$ concentrations and low $\mathrm{N}$ release rates. These composts may also have a lower value as organic fertilizer for other nutrients when compared to green and mainly VFG composts (i.e., as a source of P and K), although the differences in this study were not significant. For the blends with the woody composts, the $\mathrm{N}$ release was low, and the addition of organic fertilizers did not always result in a sufficiently high net mineral $\mathrm{N}$ release. There are important differences between batches for these compost characteristics, however, even within one type of compost, pointing at a high variability for composts [3] and the need for a batch-specific characterization.

In this study and in previous studies, it appears that the initial feedstock of the compost is a determining factor. Composts based on a woody feedstock can lead to a differentiated microbiome, including fungi with high potential for lignin degradation [32]. Feedstock determines both the suitability for use in growing media and, even more importantly, whether the compost is best for bulk use or as organic fertilizer. Categorizing subtypes of composts based on their feedstock can already partially alleviate the high variability of these materials [3]. Feedstock selection is thus an effective way for producing composts for targeted applications, including their use in horticultural substrates, and has a greater effect than additional treatment for optimizing composts after processing $[4,15]$.

\subsection{Organic Fertilizers: N Release and Microbial Activity}

Cytryn et al. [33] demonstrated that nitrification and nitrifying bacterial community dynamics in intensive soilless growing media may be significantly different from those in traditional soil-based agricultural systems. The organic fertilizer mineralization and nitrification that occurs due to microbial activity is primarily controlled by humidity and temperature [21]. The temperature and moisture conditions during incubation in our study were standardized for all materials to a level located within the optimal range for this microbial process. It is expected that the decomposition of organic fertilizers initially results in more available $\mathrm{C}$ sources in the growing medium and potentially also a reduction in oxygen availability [34]. This was confirmed by results of De Tender et al. [23], who found that during the first 6 weeks of plant growth, chitin amendment significantly increased the water-extractable $C$ content in the peat-based growing medium and resulted in higher $\mathrm{NH}_{4}-\mathrm{N}$ concentrations during the 10 -week experiment. High $\mathrm{NH}_{4}-\mathrm{N}$ concentrations and a 
high $\mathrm{NH}_{4}-\mathrm{N} / \mathrm{NO}_{3}-\mathrm{N}$ ratio may indicate the depletion of oxygen and/or a reduced nitrification. These effects were not observed in the incubation trial with the growing media blends with compost and organic fertilizers reported here. In the presence of plant roots, this balance may change, however, as roots and the microbiome in the rhizosphere may affect the oxygen availability in the blend, and due to the interactions between fertilizers, plant roots and associated microbes with the nitrification activity in the rhizosphere [35]. Higher $\mathrm{NH}_{4}-\mathrm{N}$ concentrations were only measured in some of the blends. In the $100 \%$ peat blends after 100 days, the measured concentrations were 29 and $23 \mathrm{mg} \mathrm{NH}_{4}-\mathrm{N} / \mathrm{L}$ for the blends with blood meal and chitin, respectively. In the peat-free blend with woody compost 2 and the peat-reduced blend without woody compost, both amended with chitin, the concentrations were 40 and $10 \mathrm{mg} \mathrm{NH}_{4}-\mathrm{N} / \mathrm{L}$, respectively. For the other blends, the measured concentrations were below $5 \mathrm{mg} \mathrm{NH}_{4}-\mathrm{N} / \mathrm{L}$. After 250 days, the $100 \%$ peat blend with chitin and the peat-reduced blend without woody compost with chitin still had concentrations of 15 and $9 \mathrm{mg} \mathrm{NH}_{4}-\mathrm{N} / \mathrm{L}$, respectively. The reason for the higher concentrations in the $100 \%$ peat blends may be related more to the material than to oxygen availability, as peat, after the addition of organic fertilizers, strongly accumulates ammonium due to weak nitrification [21], while other materials such as bark may show higher nitrification rates [21]. The net effect of less oxygen in the root zone due to organic fertilizers versus higher expected nitrification in the blends with woody compost resulted in higher $\mathrm{NO}_{3}-\mathrm{N} / \mathrm{NH}_{4}-\mathrm{N}$ ratios compared to the peat blend, indicating that nitrification in the peat-reduced and peat-free blends is able to overcome the risk of higher $\mathrm{NH}_{4}-\mathrm{N}$ concentrations due to the organic fertilizers, as was also observed for coir-based growing media [19]. The same study showed that these blends may benefit from a small amount of green compost (as a carrier for bacteria for the nitrification process) to stimulate the nitrification in the blend, thus reducing the risk of a too high $\mathrm{pH}$ and/or too high $\mathrm{NH}_{4}-\mathrm{N}$ concentrations in the root environment [19]. Our study confirms the study of Paillat et al. [21], i.e., that chemical and biological properties of growing media drive $\mathrm{N}$ mineralization and nitrification after organic fertilization and consequently the amount of nutrients potentially available for plant uptake.

\subsection{N Release versus Blend Composition: How to Provide Sufficient N?}

Fertilizers are expected to supply the optimal doses of nutrients within an optimal range and at the optimal speed for plant growth. Sufficiently high mineral $\mathrm{N}$ doses in the growing media blend can be provided either by adding mineral or organic fertilizers during the production of the growing media or via fertigation during cultivation. Processes resulting in the immobilization of this mineral $\mathrm{N}$ will reduce the overall availability for crops. Fertigation may result in the lowest impact of $\mathrm{N}$ immobilization processes on crop productivity, as nutrients are supplied in a more continuous way during cultivation compared to the one-time addition of mineral or organic fertilizers at the start of cultivation. Although stable materials were used in this study, and the individual materials had a low risk for $\mathrm{N}$ immobilization, the net $\mathrm{N}$ release of the blends with organic fertilizer was still low. This made it difficult to create blends with sufficiently high mineral $\mathrm{N}$ concentrations. The best results in terms of mineral $\mathrm{N}$ availability were obtained for the peat-reduced and peat-free blends made with woody compost 2 and amended with chitin. For the blends with woody compost 1 , no or only low net $\mathrm{N}$ release could be obtained after 100 days of incubation by adding the organic fertilizers. The type of compost and the type of organic fertilizer was thus more important than the blend composition, i.e., whether the peat was partly or completely replaced. The peat-reduced blends without woody compost also suffered from lower mineral $\mathrm{N}$ concentrations than the peat blends, which indicates that the issue with $\mathrm{N}$ release is also relevant for other materials.

Chitin [23] and blood meal [34,36] are considered to be organic fertilizers with high rates of $\mathrm{N}$ release. The $\mathrm{N}$ release through microbial decomposition in the peat blend was lower for chitin than for blood meal, but for the other blends it appeared to be the other way around. Although a higher dose of blood meal $(3.5 \mathrm{~g} / \mathrm{L})$ was used than for chitin 
(2 g/L), higher mineral $\mathrm{N}$ concentrations were measured for the blends with chitin for higher degrees of peat replacement. Previously, the same chitin source and dose in peat resulted in a mineral $\mathrm{N}$ release of $87 \mathrm{mg} \mathrm{N} / \mathrm{L}$ peat after 9 weeks at $20{ }^{\circ} \mathrm{C}$ [23]. Surprisingly, the net $\mathrm{N}$ release for the peat blend in the incubation trial at $15^{\circ} \mathrm{C}$ presented here was lower, although the incubation period was longer. Due to this high $\mathrm{N}$ release rate, chitin can be characterized as an organic fertilizer with fast $\mathrm{N}$ release, but it may have other functions in a growing medium blend as well, i.e., the induction of a higher disease resistance [23].

\subsection{Total Microbial Biomass: Value as Indicator and Link with N Release}

In previous work on composts and other components of growing media, the microbial composition was studied and characterized in more detail and with different techniques (e.g., [13-16]). In the current study, total microbial biomass was measured as a characteristic of either the material or the blend, and the change in microbial biomass was measured to assess the effect of adding organic fertilizer. For the materials, there were clear differences between VFG, green or woody composts versus wood fiber and bark compost. Differences between VFG composts and green composts with low initial mineral N content were also found. There was, however, no clear relationship between the microbial biomass and the $\mathrm{N}$ release capacity of the compost, except in the case of the lower net $\mathrm{N}$ release of green composts with low initial mineral $\mathrm{N}$ content. For the green composts, we conclude that the initial mineral $\mathrm{N}$ content, not the microbial biomass, is indicative for the $\mathrm{N}$ release capacity from the pure compost as well as compost blended with an organic fertilizer. In comparison to peat, all the composts had a higher microbial biomass and OUR (thus a higher microbial activity), and the values for wood fiber are in the same range as the average reported value for peat (OUR < 1, total microbial biomass: $168 \mathrm{nmol} / \mathrm{g} \mathrm{OM}$, [4]).

In contrast, for blends with or without composts, the net change in microbial biomass rather than the initial microbial biomass is indicative of $\mathrm{N}$ release from organic fertilizers. This net change was also more indicative of $\mathrm{N}$ release than the initial mineral $\mathrm{N}$ concentration of the blend. This increase in biomass is related to the process of $\mathrm{N}$ mineralization and the related decomposition of the organic fertilizers. There was a clear increase for total microbial biomass in all blends except the $100 \%$ peat blend after addition of the organic fertilizers, and the absolute increase after the addition of the organic fertilizer versus the blend without organic fertilizer was higher than the differences between the blends. No increase in microbial biomass was observed for the peat blend for both organic fertilizers. A strong increase of the total microbial biomass shortly after adding crab shell compost and other composts to soil $[37,38]$ or after adding chitin to peat $[24,39]$ in pot trials was previously reported; in most cases this coincided with a higher $\mathrm{N}$ availability. In the current research on more active substrates as peat alternatives, an inverse relationship was found between the increase in microbial biomass and the increase in $\mathrm{N}$ availability. The reason why chitin was more effective than blood meal in the blends with less peat remains unclear. It is possible that blood meal may have resulted in a higher release of $C$, inducing a higher microbial biomass, which may explain the higher increase in total microbial biomass, but this should be confirmed in future research.

Both blends with woody compost 1 , i.e., the woody compost with the highest $\mathrm{C} / \mathrm{N}$ ratio $(C / N=29)$, had no net release during the incubation with organic fertilizers. There are two hypotheses for this result: (a) due to an inhibiting factor, no activity and thus no $\mathrm{N}$ release took place or (b) microbial activity results in a lack of net $\mathrm{N}$ release due to microbial immobilization of the $\mathrm{N}$ released by the organic fertilizer.

The current results indicate that there may be evidence for the second hypothesis. The negative correlation between net $\mathrm{N}$ release and net increase in biomass supports the hypothesis of microbial $\mathrm{N}$ immobilization, i.e., the mineral $\mathrm{N}$ released by the fertilizer is re-immobilized in the short term. The seed test with cucumber does not indicate any inhibition in the blends tested. For blend M3, the added S resulted in the intended decrease in $\mathrm{pH}$, which was the result of microbial $\mathrm{S}$ transformation, and woody compost 1 had a 
higher value for OUR than woody compost 2, again indicating more intense microbial decomposition activity.

\subsection{Implications for Use of the Growing Media Blends with Woody Composts}

Organic fertilizers should be given time to start $\mathrm{N}$ mineralization before plants are grown in these blends. The lower $\mathrm{N}$ availability in some blends may be only temporary, but the possibility for storing blends for several weeks on the part of the producer or the grower may affect the feasibility of this option. The storage of the blends at a sufficiently high water content is important when it comes to enabling the microbial decomposition of the organic fertilizers $[21,40]$ and to avoid problems with germination due to high $\mathrm{NH}_{4}-\mathrm{N}$ concentrations [41]. The delayed $\mathrm{N}$ release should be taken into account to synchronize the $\mathrm{N}$ delivery by the blend with the plant's needs.

Future tests should focus on testing (a) whether higher doses of organic fertilizers are effective for releasing more mineral $\mathrm{N}$, and if the observed negative correlation between $\mathrm{N}$ release and microbial biomass also remains valid at higher fertilizer doses or slow release organic fertilizers; (b) the addition of organic fertilizers during the production of the woody composts, i.e., during the composting process on $\mathrm{N}$ release by the compost (e.g., [42]); (c) a combination of organic and mineral fertilizers; and (d) whether the presence of a crop affects the $\mathrm{N}$ release from the blends. Crops remove mineral $\mathrm{N}$ from the blends through plant uptake, and the root microbiome may also directly or indirectly affect $\mathrm{N}$ availability and nitrification $[23,35]$.

\section{Conclusions}

VFG, green or woody composts, in comparison to wood fibers or bark composts, show clearly different characteristics, including microbial biomass, stability, OM and nutrient content. Woody green composts have a higher potential to be used for the bulk replacement of peat and coir in growing media, while more nutrient-rich composts with a higher inorganic $\mathrm{C}$ content and a higher $\mathrm{N}$ release (i.e., VFG composts) should be used in lower doses, as they mainly act as organic fertilizer rather than as bulk replacement. The initial mineral $\mathrm{N}$ concentration of composts was more indicative of $\mathrm{N}$ release from pure composts than the microbial biomass, even when an organic fertilizer was added.

The added value of a woody compost in blends with a reduced peat content was assessed for two woody compost batches. Woody composts, in combination with other materials, allowed for partial $(70 \mathrm{vol} \%$ ) or complete peat replacement, and woody compost can be used at least up to $40 \mathrm{vol} \%$. The two blends containing the woody compost with the lower $\mathrm{C} / \mathrm{N}$ ratio, higher initial mineral $\mathrm{N}$ concentration, higher stability and higher microbial biomass both gave the best results in term of $\mathrm{N}$ availability when the blends were enriched with chitin as organic fertilizer.

Mixtures with a lower vol\% of peat had a higher total microbial biomass, independent of the use of organic fertilizers, while the use of blood meal as a replacement for peat resulted in an average higher microbial biomass compared to chitin, and both fertilizers gave a higher increase compared to the unfertilized blends. In contrast to the observations for pure composts, for blends with or without composts, the net change in microbial biomass rather than the initial microbial biomass or the initial mineral $\mathrm{N}$ concentration was indicative of $\mathrm{N}$ release from organic fertilizers.

Although woody composts have potential to be used in high vol\% in growing media blends, we conclude that these blends need further optimization in terms of the application of organic fertilizers. Future tests should focus on testing whether higher doses or combinations of organic fertilizers are more effective for releasing more mineral $\mathrm{N}$, and the performance of these blends should be tested for other crops and growing conditions.

Author Contributions: Conceptualization, B.V., M.R. and E.V.; methodology, B.V., K.V.L., S.O. and S.V.; formal analysis, B.V.; investigation, B.V., K.V.L., S.O. and S.V.; resources, M.R. and E.V.; data curation, B.V.; writing-original draft preparation, B.V.; writing-review and editing, all authors; funding acquisition, B.V. All authors have read and agreed to the published version of the manuscript. 
Funding: This research was partly funded and executed within the Horti-BlueC project, and partly funded by VLACO. Horti-BlueC received funding from the Interreg 2 Seas program 2014-2020 co-funded by the European Regional Development Fund under subsidy contract $\mathrm{N}^{\circ} 2 \mathrm{~S} 03-046$. Both the Province of Antwerp and the Province of East-Flanders are co-funding ILVO for Horti-BlueC.

Conflicts of Interest: The authors declare no conflict of interest.

\section{References}

1. Agarwal, P.; Saha, S.; Hariprasad, P. Agro-industrial-residues as potting media: Physicochemical and biological characters and their influence on plant growth. Biomass Convers. Biorefinery 2021, 1-24. [CrossRef] [PubMed]

2. Barrett, G.E.; Alexander, P.D.; Robinson, J.S.; Bragg, N.C. Achieving environmentally sustainable growing media for soilless plant cultivation systems-A review. Sci. Hortic. 2016, 212, 220-234. [CrossRef]

3. Atzori, G.; Pane, C.; Zaccardelli, M.; Cacini, S.; Massa, D. The Role of Peat-Free Organic Substrates in the Sustainable Management of Soilless Cultivations. Agronomy 2021, 11, 1236. [CrossRef]

4. Vandecasteele, B.; Pot, S.; Maenhout, K.; Delcour, I.; Vancampenhout, K.; Debode, J. Acidification of composts versus woody management residues: Optimizing biological and chemical characteristics for a better fit in growing media. J. Environ. Manag. 2021, 277, 111444. [CrossRef] [PubMed]

5. Neher, D.A.; Fang, L.; Weicht, T.R. Ecoenzymes as indicators of compost to suppress Rhizoctonia solani. Compost. Sci. Util. 2017, 25, 251-261. [CrossRef]

6. Herren, G.; Binnemans, I.; Joos, L.; Viaene, N.; Ehlers, R.-U.; Vandecasteele, B.; Bert, W.; Steel, H. Compost as a carrier medium for entomopathogenic nematodes: The influence of compost maturity on their virulence and survival. Biol. Control. 2018, 125, 29-38. [CrossRef]

7. Cambardella, C.A.; Richard, T.; Russell, A. Compost mineralization in soil as a function of composting process conditions. Eur. J. Soil Biol. 2003, 39, 117-127. [CrossRef]

8. Blok, C.; van der Salm, C.; Hofland-Zijlstra, J.; Streminska, M.; Eveleens, B.; Regelink, I.; Fryda, L.; Visser, R. Biochar for horticultural rooting media improvement: Evaluation of biochar from gasification and slow pyrolysis. Agronomy 2017, 7, 6. [CrossRef]

9. Escuer, O.; Karp, K.; Escuer-Gatius, J.; Raave, H.; Teppand, T.; Shanskiy, M. Hardwood biochar as an alternative to reduce peat use for seed germination and growth of Tagetes patula. Acta Agric. Scand. Sect. B Soil Plant Sci. 2021, 71, 1-14. [CrossRef]

10. Dittrich, C.; Pecenka, R.; Løes, A.-K.; Cáceres, R.; Conroy, J.; Rayns, F.; Schmutz, U.; Kir, A.; Kruggel-Emden, H. Extrusion of Different Plants into Fibre for Peat Replacement in Growing Media: Adjustment of Parameters to Achieve Satisfactory Physical Fibre-Properties. Agronomy 2021, 11, 1185. [CrossRef]

11. Vandecasteele, B.; Muylle, H.; De Windt, I.; Van Acker, J.; Ameloot, N.; Moreaux, K.; Coucke, P.; Debode, J. Plant fibers for renewable growing media: Potential of defibration, acidification or inoculation with biocontrol fungi to reduce the $\mathrm{N}$ drawdown and plant pathogens. J. Clean. Prod. 2018, 203, 1143-1154. [CrossRef]

12. Hartung, C.; Meinken, E. Fen plant biomass as growing media constituent-Reduction of nitrogen immobilization by composting. Acta Hortic. 2021, 1317, 93-98. [CrossRef]

13. Montagne, V.; Charpentier, S.; Cannavo, P.; Capiaux, H.; Grosbellet, G.; Lebeau, T. Structure and activity of spontaneous fungal communities in organic substrates used for soilless crops. Sci. Hortic. 2015, 192, 148-157. [CrossRef]

14. Montagne, V.; Capiaux, H.; Barret, M.; Cannavo, P.; Charpentier, S.; Grosbellet, G.; Lebeau, T. Bacterial and fungal communities vary with the type of organic substrate: Implications for biocontrol of soilless crops. Environ. Chem. Lett. 2017, 15, 537-545. [CrossRef]

15. Pot, S.; De Tender, C.; Ommeslag, S.; Delcour, I.; Ceusters, J.; Gorrens, E.; Debode, J.; Vandecasteele, B.; Vancampenhout, K. Understanding the Shift in the Microbiome of Composts That Are Optimized for a Better Fit-for-Purpose in Growing Media. Front. Microbiol. 2021, 12, 757. [CrossRef] [PubMed]

16. Taparia, T.; Hendrix, E.; Nijhuis, E.; de Boer, W.; van der Wolf, J. Circular alternatives to peat in growing media: A microbiome perspective. J. Clean. Prod. 2021, 327, 129375. [CrossRef]

17. Grunert, O.; Reheul, D.; Van Labeke, M.; Perneel, M.; Hernandez-Sanabria, E.; Vlaeminck, S.E.; Boon, N. Growing media constituents determine the microbial nitrogen conversions in organic growing media for horticulture. Microb. Biotechnol. 2016, 9 , 389-399. [CrossRef]

18. Cacini, S.; Di Lonardo, S.; Orsenigo, S.; Massa, D. Managing pH of Organic Matrices and New Commercial Substrates for Ornamental Plant Production: A Methodological Approach. Agronomy 2021, 11, 851. [CrossRef]

19. Verhagen, J.B.G.M. Using organic fertilisers in growing media for young plant production. Acta Hortic. 2021, 1317, 141-148. [CrossRef]

20. Gonnella, M.; Renna, M. The Evolution of Soilless Systems towards Ecological Sustainability in the Perspective of a Circular Economy. Is It Really the Opposite of Organic Agriculture? Agronomy 2021, 11, 950. [CrossRef]

21. Paillat, L.; Cannavo, P.; Barraud, F.; Huché-Thélier, L.; Guénon, R. Growing Medium Type Affects Organic Fertilizer Mineralization and CNPS Microbial Enzyme Activities. Agronomy 2020, 10, 1955. [CrossRef] 
22. Lashermes, G.; Nicolardot, B.; Parnaudeau, V.; Thuries, L.; Chaussod, R.; Guillotin, M.L.; Lineres, M.; Mary, B.; Metzger, L.; Morvan, T.; et al. Typology of exogenous organic matters based on chemical and biochemical composition to predict potential nitrogen mineralization. Bioresour. Technol. 2010, 101, 157-164. [CrossRef]

23. De Tender, C.; Vandecasteele, B.; Verstraeten, B.; Ommeslag, S.; De Meyer, T.; De Visscher, J.; Dawyndt, P.; Clement, L.; Kyndt, T.; Debode, J. Chitin in strawberry cultivation: Foliar growth and defense response promotion, but reduced fruit yield and disease resistance by nutrient imbalances. Mol. Plant-Microbe Interact. 2021, 34, 227-239. [CrossRef] [PubMed]

24. Vandecasteele, B.; Amery, F.; Ommeslag, S.; Vanhoutte, K.; Visser, R.; Robbens, J.; De Tender, C.; Debode, J. Chemically versus thermally processed brown shrimp shells or Chinese mitten crab as a source of chitin, nutrients or salts and as microbial stimulant in soilless strawberry cultivation. Sci. Total Environ. 2021, 771, 145263. [CrossRef] [PubMed]

25. De Tender, C.; Mesuere, B.; Van der Jeugt, F.; Haegeman, A.; Ruttink, T.; Vandecasteele, B.; Dawyndt, P.; Debode, J.; Kuramae, E.E. Peat substrate amended with chitin modulates the $\mathrm{N}$-cycle, siderophore and chitinase responses in the lettuce rhizobiome. Sci. Rep. 2019, 9, 9890. [CrossRef]

26. El Knidri, H.; Belaabed, R.; Abdellah, A.; Laajeb, A.; Lahsini, A. Extraction, chemical modification and characterization of chitin and chitosan: A review. Int. J. Biol. Macromol. 2018, 120, 1181-1189. [CrossRef]

27. Hartz, T.K.; Mitchell, J.P.; Giannini, C. Nitrogen and Carbon Mineralization Dynamics of Manures and Composts. HortScience 2000, 35, 209-212. [CrossRef]

28. Hartz, T.K.; Giannini, C. Duration of Composting of Yard Wastes Affects Both Physical and Chemical Characteristics of Compost and Plant Growth. HortScience 1998, 33, 1192-1196. [CrossRef]

29. Cáceres, R.; Malinska, K.; Marfà, O. Nitrification within composting: A review. Waste Manag. 2017, 72, 119-137. [CrossRef]

30. Grigatti, M.; Cavani, L.; Ciavatta, C. The evaluation of stability during the composting of different starting materials: Comparison of chemical and biological parameters. Chemosphere 2011, 83, 41-48. [CrossRef]

31. Blok, C.; Verkerke, W.; Boedijn, A.; Streminska, M.; Eveleens, B. Recirculation, circular fertilizers and resilience: The potential of growing media systems for circular production. Acta Hortic. 2021, 1317, 189-206. [CrossRef]

32. Chamuris, G.P.; Koziol-Kotch, S.; Brouse, T.M. Screening Fungi Isolated from Woody Compost for Lignin-Degrading Potential. Compost. Sci. Util. 2000, 8, 6-11. [CrossRef]

33. Cytryn, E.; Levkovitch, I.; Negreanu, Y.; Dowd, S.; Frenk, S.; Silber, A. Impact of short-term acidification on nitrification and nitrifying bacterial community dynamics in soilless cultivation media. Appl. Environ. Microbiol. 2012, 78, 6576-6582. [CrossRef]

34. Dion, P.; Jeanne, T.; Thériault, M.; Hogue, R.; Pepin, S.; Dorais, M. Nitrogen release from five organic fertilizers commonly used in greenhouse organic horticulture with contrasting effects on bacterial communities. Can. J. Soil Sci. 2020, 100, 120-135. [CrossRef]

35. Grunert, O.; Robles-Aguilar, A.A.; Hernandez-Sanabria, E.; Schrey, S.; Reheul, D.; Van Labeke, M.C.; Vlaeminck, S.; Vandekerckhove, T.; Mysara, M.; Monsieurs, P.; et al. Tomato plants rather than fertilizers drive microbial community structure in horticultural growing media. Sci. Rep. 2019, 9, 9561. [CrossRef] [PubMed]

36. Ciavatta, C.; Govi, M.; Sitti, L.; Gessa, C. Influence of blood meal organic fertilizer on soil organic matter: A laboratory study. J. Plant Nutr. 1997, 20, 1573-1591. [CrossRef]

37. Ebrahimi, N.; Viaene, N.; Vandecasteele, B.; D’Hose, T.; Debode, J.; Cremelie, P.; De Tender, C.; Moens, M. Traditional and new soil amendments reduce survival and reproduction of potato cyst nematodes, except for biochar. Appl. Soil Ecol. 2016, 107, 191-204. [CrossRef]

38. Debode, J.; Ebrahimi, N.; D’Hose, T.; Cremelie, P.; Viaene, N.; Vandecasteele, B. Has compost with biochar added during the process added value over biochar or compost to increase disease suppression? Appl. Soil Ecol. 2020, 153, 103571. [CrossRef]

39. Debode, J.; De Tender, C.; Soltaninejad, S.; Van Malderghem, C.; Haegeman, A.; Van der Linden, I.; Cottyn, B.; Heyndrickx, M.; Maes, M. Chitin Mixed in Potting Soil Alters Lettuce Growth, the Survival of Zoonotic Bacteria on the Leaves and Associated Rhizosphere Microbiology. Front. Microbiol. 2016, 7, 565. [CrossRef] [PubMed]

40. Blok, C.; Eveleens, B.; van Winkel, A. Oxygen use in compost storage as influenced by moisture, temperature and degradability. Acta Hortic. 2019, 1266, 291-300. [CrossRef]

41. Diaz-Perez, J.C.; Keith Jenkins, W.; Pitchay, D.; Gunawan, G. Detrimental Effects of Blood Meal and Feather Meal on Tomato (Solanum lycopersicon L.) Seed Germination. HortScience 2017, 52, 138-141. [CrossRef]

42. Cayuela, M.L.; Mondini, C.; Insam, H.; Sinicco, T.; Franke-Whittle, I. Plant and animal wastes composting: Effects of the N source on process performance. Bioresour. Technol. 2009, 100, 3097-3106. [CrossRef] [PubMed] 